\title{
"O monopólio da cabo-verdianidade": A morte do ouvidor (2010), de Germano Almeida, e o desafio de recontar o passado
}

\author{
Paulo Victor Alves Lima da Silva* \\ Doris Wieser** \\ Todos nós éramos \\ bastardos da cor \\ excessivamente clara \\ bastardos da cor \\ excessivamente escura \\ brancos da terra \\ descendentes dos venerandos moradores de santiago \\ José Luís Hopffer Almada
}

\section{A morte do ouvidor e a morte do coronel}

Na vila da Praia, em Cabo Verde, durante a noite de 13 de dezembro de 1762, "um bando de homens armados, após arrombarem a porta à machadada, entram na residência do ouvidor e matam-no, usando como armas do crime zagaias, facas e machados" (AlmeidA, 2010, p. 321-322). Em 1764, o coronel António de Barros Bezerra de Oliveira e mais nove cúmplices são presos em Cabo Verde pelo assassinato do ouvidor João Vieira de Andrade, julgados e condenados à morte, enforcados no Rossio, em Lisboa, sem provas concludentes nem confissão. Decapitados, em 18 de fevereiro de 1765, suas cabeças são expostas na Praia.

São esses eventos que Germano Almeida explora centralmente no romance A morte do ouvidor, publicado em 2010. Entretanto, a abordagem desse episódio pelo autor cabo-verdiano ultrapassa uma simples recuperação dos acontecimentos como consta nos arquivos. No início do livro, em "uma nota necessária", além de indicar as fontes historiográficas e historiadores com quais trabalhou para escavar as informações que constam no livro, Almeida já deixa um alerta de que "tudo que não for historicamente confirmado deve ser tido como invenção do au-

\footnotetext{
Graduando em Letras pela Universidade Estadual Paulista, São Paulo, SP, Brasil e bolsista de graduação-sanduíche na Faculdade de Letras da Universidade de Coimbra, Portugal. E-mail: paulo.victor@unesp.br.

* Doutora em Literatura Ibero-Românica e professora da Universidade de Coimbra na área das Literaturas Africanas de Língua Portuguesa, Coimbra, Portugal. E-mail: dwieser@uc.pt.
} 
tor" (AlmeidA, 2010, p. 5), ponto chave para entendermos os contornos que conduzirão a narrativa.

Desde o início é evidente a relação dessa obra com um romance anterior de Germano Almeida: Eva (2006). Os personagens Luís Henriques e Eva já tinham aparecido nesse romance e são revisitados aqui. Essa ligação também possibilita reconhecer o narrador homodiegético, que não é nomeado, mas pode ser identificado com o jornalista Reinaldo Tavares. Em certa medida, o autor retoma também a constelação e o ritmo do romance anterior: as conversas e os passeios dos amigos, regados a muito álcool, embora aconteçam em locais diferentes (no caso de Eva em Lisboa, e no caso de A morte do ouvidor em Santiago e Ribeira Grande). É na interação entre o narrador, um cabo-verdiano que vive na ilha de Santiago, e Luís Henriques, nascido na mesma ilha, mas emigrado em Lisboa onde trabalha como professor de liceu, que essa trama será desenvolvida, com os dois amigos dedicados à organização de um livro para narrar a trajetória do coronel António de Barros Bezerra de Oliveira. Nessa jornada repleta de digressões históricas, a dupla amplia a linha do tempo e produz de maneira fragmentária um painel da vida política, econômica e social da Cidade Velha (Ribeira Grande) ${ }^{1}$ do século XVIII, em um "vai-e-vem" à acontecimentos dos séculos anteriores e posteriores, percorrendo uma série de governadores, ouvidores, famílias ilustres, conluios, intrigas, assassinatos e figuras históricas emblemáticas.

Assim, o enredo do romance de Germano Almeida divide-se em dois eixos: o da "estória da História", no passado, em que são apresentadas as figuras históricas e desvelados os episódios que culminaram no caso da morte do ouvidor e as suas consequências, e o dos "contadores", no presente, onde o narrador e Luís Henriques debatem a composição dessa "estória", tentando decidir quais as configurações mais adequadas para elaborar o livro que pretendem escrever.

A historiadora cabo-verdiana Iva Cabral (2012) entende que António de Barros Bezerra de Oliveira é o maior representante da elite cabo-verdiana do século XVIII. Essa elite constitui uma terceira fase da elite insular, é mestiça e endógena, composta pelos denominados "brancos da terra" (majoritariamente pardos e pretos nascidos nas ilhas que, vivendo dentro do sistema racista, aspiravam "ser brancos”), grandes proprietários rurais que enriqueciam com a exploração da terra e o comércio com os navios. Os "brancos da terra" passam a controlar gradualmente todas as instituições do poder local em Santiago e assumir os governos interinos na Câmara, pelo que Cabo Verde foi conquistando cada vez mais autonomia política e econômica frente aos oficiais régios. Nesse contexto, o coronel Bezerra de Oliveira, seguindo os passos da sua família que historicamente se destacava na

\footnotetext{
A Cidade Velha, fundada em 1462 e situada no conselho de Ribeira Grande de Santiago, foi a primeira capital de Cabo Verde, tendo sido substituída pela Praia em 1769. O processo da sua decadência, inclusive o ataque do corsário francês Jacques Cassard em 1712, é um dos temas abordados pela dupla no romance. A cidade foi classificada pela UNESCO como Património Cultural da Humanidade em 2009. Fonte: http:www.patrimoniocultural.gov.pt/pt/patrimonio/patrimoniomundial/origem-portuguesa/cidade-velha/. Último acesso em 24 de janeiro de 2021.
} 
ilha, chega a ocupar todos os cargos do poder local, e é consagrado com títulos como "régulo", "príncipe" e "rei" de Cabo Verde.

Apoiada nisso, Iva Cabral (2012), que é uma das fontes indicadas por Almeida, assinala um outro dado que será o ponto crucial na reelaboração histórica dos dois amigos: o viés político da condenação do coronel e a atuação do Marquês de Pombal, secretário de Estado durante o reinado de D. José I, de 1750 a 1777, conhecido pela sua mão dura, como sublinha, na ficção, Luís Henriques: "como sabes Pombal extinguiu a Inquisição mas herdou-lhe todos os métodos brutais com os quais se vingava daqueles que se permitiam opor-se-lhe" (AlmEIDA, 2010, p. 251). Essa poderosa oligarquia, ao tomar ciência dos planos da Companhia Geral do Grão Pará e Maranhão, que corriam secretamente (fundada pelo Marquês com o objetivo de monopolizar a atividade comercial na região, nomeadamente o tráfico de escravizados, e de assumir o governo político e militar de Cabo Verde, suprimindo a relativa autonomia do arquipélago e arrastando-o para a dependência e decadência), opõe-se severamente e resiste a esse domínio. Com o assassinato do ouvidor João Viera de Andrade, "que parece ter sido mandado para Cabo Verde como uma espécie de braço armado do grande Marquês de Pombal” (AlmeıdA, 2010, p. 283) e a vinculação de Bezerra de Oliveira ao crime, a Coroa portuguesa destrói o poderoso grupo, degola os poderes locais e repõe a ordem colonial, e a isso segue-se justamente a afirmação do controle da Companhia nas ilhas. Mais do que somente descrever o episódio da morte do ouvidor, como poderia sugerir o título, o itinerário dos dois amigos pelos textos e pelos vestígios arquitetônicos da Cidade Velha explora um novo rumo no panorama histórico de sua terra natal.

\section{A cabo-verdianidade entre a África e a Europa}

Juntamente ao argumento histórico, é interessante chamar a atenção para a formação da identidade cultural em Cabo Verde, a "única nação do mundo orgulhosamente mestiça" (AlmeidA, 2010, p. 56). Ao ser descoberto pelos portugueses, o arquipélago era deserto, pelo que a sua colonização apresenta caraterísticas diferentes da de outros espaços colonizados, nomeadamente dos do continente africano. Em Cabo Verde, a chegada de portugueses (e de outros europeus) ocorreu quase ao mesmo tempo da chegada dos africanos (de diferentes origens), tendo sido o objetivo principal da colonização do arquipélago o tráfico transatlântico de pessoas escravizadas. Este fato, junto com a insularidade do território, teria criado uma aculturação mais rápida e profunda do que nas colónias do continente africano, pelo que a população cabo-verdiana se tornou relativamente homogênea (Hamilton, 1984, p. 93). À diferença de outras colônias, o regime de Indigenato não foi aplicado em Cabo $\operatorname{Verde}^{2}$ pelo que a população mestiça e negra tinha uma maior possibilidade de ascensão social do que nas colônias do continente africano. Acrescenta-se a isso, o fato de Cabo Verde ter sido pouco atrativo para fun-

2 O diploma legislativo n. $^{\circ}$ 956, de 4 de novembro de 1947, confirma a não aplicabilidade do Indigenato a Cabo Verde (MADEIRA, 2016, p. 74), tendo sido essa uma prática de longa data. 
cionários e colonos portugueses, uma vez que, devido às suas condições climáticas, a possibilidade de enriquecer no setor agrícola era reduzidíssima, pelo que a Coroa concedeu certos privilégios às pessoas nascidas nas ilhas. Podiam assumir posições na administração colonial, situação referida também no romance:

Porém, com o passar do tempo, já ninguém de qualidade e merecimento se oferecia para vir para Cabo Verde prestar serviço, e as razões eram variadas: para além de que enriquecer aqui custava os olhos da cara, obrigando o pessoal à prática de toda a espécie de falcatruíces e muitas outras vilanias, havia também a malignidade do clima de Santiago que o ouvidor Botelho, uns bons anos antes, já tinha classificado de inimigo cruel da vida humana, principalmente dos homens brancos. 'É terra que mais parece cemitério que povoação', tinha ele lamentado junto da coroa (AlmeidA, 2010, p. 41).

No entanto, a crescente autonomia que tinha alcançado o arquipélago, território de grande importância estratégica, levou à condenação e ao enforcamento desta elite em 1765. Mais de um século depois do sucedido, com o fim da escravatura em 1876 e o consequente desinteresse de Portugal no território, fortificou-se novamente a posição social dos mestiços cabo-verdianos. Possuindo uma melhor formação e um maior grau de assimilação cultural que os "indígenas" do continente africano, foram enviados para outras colônias portuguesas para desempenhar funções administrativas onde ocupavam um lugar ambíguo no sistema colonial.

Perante esta situação, a população de Cabo Verde teve dificuldades em se assumir simplesmente como africana e juntar-se sem mais às lutas de libertação contra o colonialismo português. O próprio Germano Almeida refere essa dificuldade na crónica "Uma forma de identidade africana":

Vivíamos, pois, na tranquila segurança de sermos cabo-verdianos, com a inofensiva circunstância adjuvante de sermos também portugueses, quando essa pacatez foi abruptamente sobressaltada nos anos 6o-70, com a agitada revelação de que Cabo Verde também era África [...], tivemos que aprender que também fazíamos parte dos condenados da terra, que igualmente pertencíamos à grande massa humana meio gente meio besta chamada de indígena (AlmeidA, 1998, p. 15).

O autor afirma ainda que a aceitação da africanidade dos cabo-verdianos não se prendia tanto com a experiência de uma realidade colonial comparável à do continente africano, mas sim com "um tremendo esforço de solidariedade para com desconhecidos irmãos de sofrimento", uma vez que "a simples situação de colonizados obrigava-[n]os a estar sempre e em todos os tempos ao lado dos oprimidos do mundo inteiro, muito embora fosse verdade que o colonizador em Cabo Verde estivesse representado quase exclusivamente por funcionários cabo-verdianos" (Almeida, 1998, p. 15). 
Por conseguinte, a identidade nacional cabo-verdiana é alicerçada em elementos que se diferenciam das identidades construídas no continente africano. Destacam-se a afirmação e valorização da mestiçagem, o crioulo como língua materna, a emigração devida às condições climáticas, a insularidade como fator de isolamento. ${ }^{3}$

Nesse processo, algumas fases de construção identitária foram debatidas como manifestações e posicionamentos que ora reivindicavam a matriz cultural europeia ora enalteciam a matriz africana. A geração de 1930 à volta da revista Claridade, fundada por Manuel Lopes, Baltasar Lopes e Jorge Barbosa, e figuras como Amílcar Cabral, líder do PAIGC durante a luta pela libertação, são notórias num e noutro sentido.

Entre os claridosos, a matriz europeísta foi interpretada, implicitamente, como elemento dominante. Daí a decepção da elite intelectual cabo-verdiana, quando, em 1951, Gilberto Freyre visita o arquipélago por convite do Estado Novo e sentencia, no seu livro Aventura e Rotina (1952), que a população das ilhas é mais dominada pelo elemento africano que as áreas mais negroides do Brasil (HAMILTON, 1984, p. 99; CAStelo, 1999, p. 93). Como consequência, a atração das teorias de Freyre ter-se-ia dissipado, de acordo com Laranjeira (2011, p. 26). Para além disso, a concepção da crioulidade dos claridosos foi, em 1963, severamente contestada por Onésimo Silveira que a denunciou como inautêntica e elitista, seja a acusação justa ou não (LARANJEIRA, 1995, p. 191; 220-22). De qualquer forma, o credo mais generalizado sobre a cabo-verdianidade acabou por ser, nem a perspectiva europeísta, nem a africanista, senão a que Madeira (2016, p. 54) chama de "singularista" e que se alicerça na ideia da fusão cultural de um povo profundamente miscigenado cuja luta não se dirigia tanto contra o colonialismo e o racismo, mas sim contra as difíceis condições climáticas. ${ }^{4}$ Portanto, nem europeu nem africano, os cabo-verdianos afirmam-se como um povo singular sui generis.

A ideia implícita a esta concepção da cabo-verdianidade, a de que Cabo Verde é um país isento de racismo ou de um racismo apenas tênue, é problemática e será corrigida de maneira jocosa em A morte do ouvidor. O narrador e Luís Henriques referem o quanto a elite cabo-verdiana se esforçava por se manter branca: "ora se é verdade que nessa época a conjunção carnal entre brancos plebeus ou degredados residentes na ilha e negras e mulatas já era facto banal, [...], não o era, porém, para as famílias com pergaminhos de nobreza e que desejassem manter-se inteiramente brancas" (AlmEIDA, 2010, p. 176). A diferença de classe, de fato, é identificada como divisor de águas quanto à miscigenação dos cabo-verdianos. O romance recalca $\mathrm{o}$

3 Veja-se também a descrição de elementos culturais basilares da cabo-verdianidade que fornece Madeira (2016, p. 56-61) e que inclui língua, música, gastronomia, religião, casamento, sementeira e rituais fúnebres.

4 A narrativa do povo em constante luta contra o clima semiárido foi cunhada por Manuel Lopes no romance Os flagelados do vento leste (1960), e eternizada por Ovídio Martins no poema "Flagelados do vento leste" (1962) 
alto grau de miscigenação entre as classes populares por um lado e a abstenção de relações inter-raciais entre os membros da classe alta por outro:

[Naquele tempo] subsistia a individuação de 'vizinhos homens brancos e honrados', diferenciados dos 'vizinhos negros' com os quais não se misturavam nem na igreja, basta ter em conta a existência da igreja de Nossa Senhora do Rosário dos Pretos [...]. Nos bairros sim, nos bairros é que a miscigenação florescia como erva daninha em terra fértil, e o resultado é este nosso povo que até se dá ao luxo de afirmar a existência de uma raça cabo-verdiana (AlmeidA, 2010, p. 22).

A concepção da cabo-verdianidade como uma identidade que se prende com a miscigenação e a crioulização seria, portanto, uma concepção baseada no que acontecia em setores populares, reservando-se a elite a exclusividade da branquidão ou, caso necessário, do re-branqueamento. O romance nos apresenta uma sociedade que, se por um lado é sem dúvida profundamente miscigenada, por outro se revela classista e, por este viés, espelha o racismo do sistema colonial. Neste contexto, resulta interessante questionar a cor da pele do protagonista da "estória da História”, o chamado rei ou príncipe de Cabo Verde, o coronel António de Barros Bezerra de Oliveira. Eis os dados que a dupla junta sobre o pai deste personagem, João Pereira de Carvalho:

Nasceu em Santiago em 1686 e, ao que tudo indica, de mulher pelo menos não branca. Isso porque é descrito algumas vezes como branco da terra, outras vezes como mulato e até mesmo como preto, o que desde já deita por terra a pretensão do nosso herói de ser branco como os do reino e não como os de Cabo Verde (Almeida, 2010, p. 201).

Trata-se, portanto, de um indivíduo cuja família já tem um histórico de miscigenação apesar da tez relativamente clara. Em outros momentos narram-se as lutas cômicas ou até grotescas de outros membros da elite cabo-verdiana contra o "vício" da miscigenação de parentes seus. A descrição dos enforcados, cujas cabeças foram enviadas à Praia e espetadas a modo de exemplo, demonstra que eram majoritariamente pardos e negros:

Sebastião Correia, preto; Domingos da Veiga, pardo; Feliciano de Barros, preto; Francisco de Spínola, pardo; Jorge Semedo, preto; Manuel Correia, pardo; Luís Antunes, preto. Cada vez mais próximo, Manuel José de Oliveira, natural de Lisboa, capitão João Coelho Monteiro da Fonseca, natural de Cabo Verde. E por fim [...] António de Barros Bezerra de Oliveira (AlmeidA, 2010, p. 382). 
Assim, a "estória da História" deste romance insere-se na época de miscigenação da elite local em que os brancos perdem a sua importância na administração das ilhas. $^{5}$

\section{Paródia e diversão}

Assumir a tarefa historiográfica dos "contadores" da estória parece inspirar seriedade e responsabilidade, todavia, isso é contrabalançado pela dinâmica dos dois personagens que pretendem tornar-se autores de um livro, repleta de ironia, irreverência e regada a muitas taças de vinho. A narrativa dos acontecimentos históricos é estruturada de forma fragmentária no diálogo entre o narrador e Luís Henriques ao longo dos dez dias em que cada um expõe o resultado de suas leituras de obras de historiadores e das consultas à documentos e mapas. Esse dueto mostrase afiado e irônico. Ambos injetam as suas subjetividades, estilos e preferências individuais na narração. Eles levantam questionamentos sobre as ideias de isenção, imparcialidade e verdade dos discursos históricos, dominados massivamente pela visão colonial. Assim, exibem como os materiais e testemunhos que utilizam obviamente servem aos propósitos de quem os escreveu:

Lembra-te que estás a falar apenas através das palavras deixadas pelo ouvidor, notou Luís Henriques, não conhecemos a versão do governador, não sabemos se é verdade tudo o que diz o outro. Tanto pior para o Tigre ${ }^{6}$ disse eu maldoso, ele que deixasse memória como fez o seu inimigo (AlmeIdA, 2010 p. 113-114).

Assim, os sujeitos e a realidade histórica são diversas vezes refutados e deliberadamente adulterados, motivos de troça e expostos de forma risível, alvos da "raiva com efeito retroativo" dos autores, como o padre Vieira aos olhos do narrador: "um cínico, esse padreca ordinário, um relapso da pior espécie, explodi, foi pena a Inquisição não o ter assado!” (AlmEIDA, 2010, p. 130).

No decorrer do romance, as provocações entre os dois amigos deixam bastante evidente o quanto são profundamente conscientes dos excessos que cometem e dos limites que enfrentam no processo de elaboração do livro. Além da "nota necessária" incluída por Almeida no início da obra, as referências às fontes consultadas são constantes no desenrolar da história. "Plagiar não, citar, faz favor: Daniel Pereira, algures na internet, e o sempre inefável Senna Barcelos" (Almeida, 2010, p. 122). Da mesa forma revelam a sua percepção sobre os possíveis defeitos que podem ser apontados pelo futuro público leitor, como o excessivo número de personagens lembrados "no meio desta barafundada história com tanta gente"

5 Madeira realça este facto na época em questão e fundamenta-o com os seguintes números (extraídos de Chelmicki \& Varnhagen, 1841): "no início do século XIX, segundo os dados de recenseamento, Cabo Verde contava com um número acentuado de habitantes negros e mulatos, 5.109 pretos escravos, 27.290 pretos forros, 25.250 mulatos e apenas 1.752 brancos" (2016, p. 53).

6 Bartolomeu de Sousa de Brito Tigre foi governador de Cabo Verde de 1764 a 1766. 
(Almeida, 2010, p. 128), a desmedida expansão na linha do tempo ao questionar "não estaremos a recuar excessivamente no tempo?" (AlmEIDA, 2010, p. 187) ou as demasiadas divagações históricas em alguns momentos, como mostra uma provocação feita a Luís Henriques "durante um capítulo inteiro preferiste perder-te em, não direi inúteis, mas pelo menos desnecessárias digressões históricas como se, em vez de num trabalho sério e objectivo, estivéssemos passeando em um piquenique dominical" (ALmeIDA, 2010, p. 237).

O empenho com o projeto é ironizado, pois apesar de ser o grande motivo que permitiu o encontro da dupla em Cabo Verde, o caráter sério do empreendimento é compensado frequentemente em ocasiões de descontração, em jantares ou com o consumo de várias garrafas de vinho português trazido por Luís Henriques. A falta de compromisso com a conclusão do livro é evidenciada pelo fato de não estabelecerem nenhuma previsão concreta para a realização da escrita das informações intercambiadas. Até mesmo refletem sobre a precariedade do mercado editorial nas ilhas, com editoras pequenas e sem recursos. O próprio narrador nos confessa, com o habitual tom jocoso: "mas na mesma brindemos a este símbolo final de dez longos dias, que daqui a alguns meses apresentaremos ao público como tendo sido de intenso trabalho e cansaço, mas que cá entre nós, para que ninguém nos ouça, sabemos em consciência que foram de deliciosa paródia e diversão" (AlmeidA, 2010, p. 359-36o).

Esses elementos definidores da elaboração metaficcional e a sua relação com a historiografia na obra de Germano Almeida, poderiam encaminhar ao que diz Hutcheon (1991) sobre metaficção historiográfica. O termo refere-se a textos metaficcionais que, num primeiro momento, estabelecem as diferenças entre historiografia e ficção, pressupondo os seus contratos genéricos, para, num segundo momento, contrariá-las. São textos que põem em causa, por um lado, a possibilidade de diferenciar entre a representação autêntica e a cópia inautêntica e, por outro, os preceitos de originalidade artística e da transparência da referencialidade histórica (Hutcheon, 1991, p. 146-147). Entretanto, como alerta Pires (2016), ainda que não se elimine a possibilidade do questionamento da linguagem como forma de conhecer o mundo integrar o projeto de Almeida, não é possível compreender o romance somente dentro dessa visão meramente metaficcional.

O primeiro ponto a analisar nessa perspectiva é o posicionamento dos dois amigos em relação ao "príncipe de Cabo Verde". O narrador sempre deixa evidente a sua afeição pela figura do coronel, considerando-o "um grande homem que marcou uma época" (AlmEIDA, 2010, p. 9), e assume não acreditar em neutralidade quando o amigo zomba de sua forma apaixonada de falar sobre o caso de mais de duzentos e cinquenta anos: "Bezerra de Oliveira não merece ser humilhado pelo poder dos homens, e se para o evitar fica necessário adulterar um pouco a história, pois bem, que então se adultere um pouco a história" (ALMEIDA, 2010, p. 8). Luís Henriques apesar de não compartilhar a "paixão" na mesma intensidade, também não deixa de expressar a sua admiração pelo poder e a importância que o coronel 
desempenhou nas ilhas e as razões que levaram à sua derrocada, considerando-as uma grande história que não deveria ficar esquecida nos arquivos. É justamente dele que parte a iniciativa de escrever um livro que discorra sobre esses fatos, e ele mesmo realiza uma extensa pesquisa nos arquivos portugueses para encontrar documentos sobre o episódio.

Assim, com o estudo minucioso dos artigos de historiadores, cartas, testemunhos, provas judiciais, os personagens começam a construir a sua interpretação e projetá-la na história do arquipélago, contestando a forma como os acontecimentos foram registrados pelas ordens da Coroa portuguesa, que colocam Bezerra de Oliveira na posição de inimigo e assassino. A imagem que pretendem divulgar é a do coronel enquanto sujeito poderoso e que exercia controle, representante da oligarquia que dominava Cabo Verde com relativa autonomia e que se opôs ao controle do Marquês de Pombal e da Companhia do Grão Pará e Maranhão. Apropriando-se dos dados e exercendo a liberdade de examiná-los de acordo com a "estória" do passado que desejam traçar, ao mesmo tempo em que operam essas autorreflexões sobre os seus métodos e fontes, todo o processo de revisão operado no romance pelos dois amigos busca colocar o "régulo de Cabo Verde" na posição de personagem principal, um "branco da terra", preocupado com a manutenção do poder do seu clã e das elites locais em geral.

Essa postura dos amigos, que parece expressar a do próprio Germano Almeida, insere-se precisamente com o que Iva Cabral (2012) sugere, quando aponta para a relevância de realçar a história da nação cabo-verdiana com figuras humanas, através de uma iniciativa que recupere a memória de pessoas como António de Barros Bezerra de Oliveira. Insere-se também na observação de João Paulo Madeira quem afirma, entre outros, que em Cabo Verde "a Nação precede em séculos, a criação do Estado independente, o que a diferencia da maioria dos países africanos, onde o Estado é que tem vindo a promover a formação da Nação" (2010, p. 74).

Nesse sentido, apesar de Germano Almeida evitar o rótulo de romance histórico para definir sua obra, é possível encaixar o romance de Almeida no argumento de Dalley (2014), que indica a realist imperative como fator que caracteriza o romance histórico pós-colonial. Dalley considera esse aspecto como especificamente póscolonial, pois constitui uma resposta ético-política e estética ao valor cultural da história em sociedades estabelecidas na base de ocupações coloniais.

[...] the genre is realist insofar as it asserts the epistemological claim that fictional narratives about history ought to be treated as serious interpretations of the past, open to dialogue with rival accounts and archival sources. In other words, the historical novel's realism arises from its commitment to norms of plausibility and verisimilitude that frame narratives as meaningful contributions to knowledge (DALLEY, 2014, p. 9).

O romance de Germano Almeida também partilha as caraterísticas do romance histórico pós-colonial, resumidas por Edvaldo Bergamo (2017, p. 57-58), entre elas, 
a desmistificação da história hegemônica, a edificação de uma versão disruptiva dos factos, a perspetiva preferencialmente paródica ou carnavalizada dos eventos e a indagação de campos ideológicos em disputa, além da já mencionada metaficção. Os mecanismos metaficcionais empregados no romance, antes de tudo, podem ser entendidos como artifícios para lidar com os próprios limites que a escrita dessa história cria. Almeida atesta que sua concepção do romance é "como se fosse um romance de personagens da atualidade que contam a história do antigamente, porque não me sentia balizado para escrever um romance histórico" (RATTNER, 2010).

Logo, o jogo irônico e constante entre os dois potenciais escritores dentro do enredo escancara as possíveis "falhas" antes que elas sejam mencionadas por eventuais críticos, debatendo a verossimilhança dos documentos consultados e confessando abertamente a adulteração da realidade histórica para servir aos interesses pessoais. Mas afasta-se do que Hutcheon (1991) aborda sobre os autores que desenvolvem a metaficção historiográfica, porque não são puramente artifícios para desconstruir a narrativa histórica e reconhecer sua acessibilidade textualizada. O romance assimila os dados históricos, afirma um posicionamento ético para as contradições da história cabo-verdiana e oferece uma resposta que representa "uma transferência simbólica de poder" (PIREs, 2016, p. 213). Ao apoderar-se dos arquivos para defender uma visão da história de Cabo Verde que valorize e dê protagonismo aos elementos nacionais, para romper com o domínio do colonizador sobre o seu passado e preencher as lacunas criadas no caminho, projetando uma outra noção de identidade cultural do arquipélago e do "ser cabo-verdiano".

\section{Recontar um herói polêmico}

Por esse ângulo, é pertinente recorrer a Stuart Hall que ao comentar sobre as nuances das identidades culturais, discorre sobre "a identity not grounded in the archaeology, but in the re-telling of the past" (HALL, 1990, p. 224) ressaltando o papel de "hidden stories" para o desenvolvimento de muitos movimentos sociais anticoloniais. Nesse suporte de que "identities are the names we give to the different ways we are positioned by, and position ourselves within, the narratives of the past" (HALl, 199o, p. 225) apoia-se A morte do ouvidor, pois é no processo de re-telling operado pelos personagens que Germano Almeida introduz discussões e reflexões sobre a cabo-verdianidade e sobre a dignidade do povo cabo-verdiano. O re-telling é feito justamente a partir de uma outra perspectiva, que já não é a das fontes históricas, a do poder colonial, mas também não é a dos "condenados da terra" de Frantz Fanon, mas sim, da elite local entendida na perspectiva singularista ${ }^{7}$ como algo novo que virá a ser a base da cabo-verdianidade. Os "contadores” da estória, Reinaldo Tavares e Luís Henriques, são eles próprios herdeiros e continuadores dessa cultura sui generis formada através de séculos.

7 Madeira (2016, p. 72) conta Germano Almeida entre os cabo-verdianos que defendem uma perspectiva "singularista". 
A abordagem da trajetória de Bezerra de Oliveira, recontada nessa outra perspectiva, acaba por criar um esboço de herói. Ultrapassando as dicotomias de inocente-culpado, vítima-algoz, já que as fontes não oferecem uma solução categórica para o caso, a escolha e o interesse pelo coronel é fundamentalmente para apreciar e destacar a capacidade de resistência dos cabo-verdianos, e mostrar um exemplo de grandiosidade do passado. Ainda que se trate de um "branco da terra", representante de uma poderosa oligarquia, e que pode ter agido por diversas vezes de maneira no mínimo questionável e exploratória para manter o seu poder e privilégio, em detrimento de outros, é inegável a atitude de oposição e afronte ao poder colonial e à monopolização comercial da Companhia do Grão Pará e Maranhão para defender a liberdade, a autonomia política e econômica do domínio oligárquico das ilhas. A "estória" que o romance conta intervém no que ficou conhecido da sua condenação, recusa-a como simplesmente a sentença de um criminoso e traidor vil, mas tenta angariar entre o público leitor adeptos/as do entendimento do episódio como uma decapitação orquestrada politicamente pelo Marquês de Pombal para livrar-se dos empecilhos aos seus planos para a Companhia.

Contudo, a tarefa de recontar o passado adotada por Almeida não se limita somente a figura do "rei da ilha de Santiago". Essa narrativa é expandida com a comparação entre o passado e o presente das ilhas e com os próprios elementos da vida dos "contadores", tecendo outras reflexões sobre a identidade cultural e os processos históricos do arquipélago, que devem ser olhadas mais atentamente.

\section{(In)dependência?}

O narrador, principalmente, intercala o re-telling do passado (não somente do século XVIII, mas também do período da independência de Cabo Verde, por exemplo) com a análise crítica da atualidade das ilhas, exibindo orgulhosamente os aspectos positivos do progresso e desenvolvimento, mas também os aspectos negativos consequentes do neoliberalismo que entrou com força no arquipélago nos anos de 1990, descrevendo a degradação da natureza e do ambiente urbano e a corrupção do cenário político. A situação económica contemporânea de Cabo Verde e as tentativas de estabelecer relações com a África e a Europa, também são temas de reflexão. Enquanto Cabo Verde se associa em 1977 à Comunidade Económica dos Estados da África Ocidental (CEDEAO), as negociações com a União Europeia são mais tardias. Começam depois da queda do Muro de Berlim, do enfraquecimento dos laços dos países africanos com os países socialistas e da chegada do neoliberalismo: "desde 1991, somos um país aberto ao mundo e ao consumo, endividado até aos ovos é verdade, porém farto de todas as coisas boas que a indústria produz" (AlmeIDA, 2010, p. 330). Assim, 1991, o ano das primeiras eleições multipartidárias não é relembrado aqui como um avanço da democratização do país, mas como o início de uma época de liberalização económica problemática.

De facto, só em 2007, três anos antes da publicação do romance, Cabo Verde estabelece uma "parceria especial" com a União Europeia (MADEIRA, 2016, p. 69), 
motivo de repetida troça da dupla de amigos que veem na apetência dos caboverdianos de se aproximarem à UE uma incapacidade de abdicar da tutela do antigo colonizador. O narrador, seguindo a linha de entrelaçar passado e presente, exprime críticas mordazes sobre o fracasso da descolonização de mentalidades:

Se reparares, no breve período que vai de 1975 a 1990 ainda acreditámos em nós e ainda seguimos o lapidar princípio de Cabral de pensarmos pelas nossas próprias cabeças. Porém, a alegria foi breve, rapidamente voltámos aos paraninfos que chegam de fora porque continuámos a ser um povo que precisa de orientadores, que precisa de mestres, de messias, talvez até de donos, razão tinha o ministro fascista de Salazar, de nome Silva Cunha, quando dizia que os pretos precisam sempre estar enquadrados para terem alguma serventia (AlmeidA, 2010, p. 287).

Com esta provocação, o narrador alerta para a necessidade de os cabo-verdianos se apropriarem decisiva e definitivamente do seu destino e da sua história. A contínua relação presente-passado, buscando explicar as origens dos dilemas da pátria e até mesmo indagações para o futuro, também indicam o quanto o livro não pode ser reduzido a mera reflexão metaficcional.

\section{"Quem ficou" versus "quem partiu"}

Os escritores desse "projeto audacioso" caracterizam duas vivências da população cabo-verdiana: o narrador é habitante da ilha de Santiago, vive a experiência insular e nunca deixou a sua terra, e Luís Henriques é um emigrante, vivendo já há muitos anos em Portugal. Segundo Góis (2006), a emigração é de tal forma um fenômeno estruturante na formação da nação cabo-verdiana que Cabo Verde é um "estado que já nasce transnacionalizado", sendo um dos poucos países com uma emigração ininterrupta nos últimos séculos. Baseado nesse dado, frente ao desafio de pensar uma identidade coletiva nesse contexto, o investigador trata da existência de uma "identidade étnica transnacional cabo-verdiana". Lopes Filho também refere a emigração como enraizada na própria origem e constituição da sociedade cabo-verdiana, "fazendo mesmo parte do seu imaginário, pois está também presente na tradição oral, na música, na literatura, etc., como características marcantes deste povo" (Lopes FilHo, 2010, p. 138).

Tendo em vista a profundidade dos movimentos emigratórios para o percurso histórico e a identidade cultural do arquipélago, é possível apreender as tensões que a presença desse tópico traz à tona em $A$ morte do ouvidor e evidencia que a identidade transnacional, de que fala Góis, não é homogênea e isenta de invejas, condescendências ou até raivas por parte de "quem ficou" e/ou "quem partiu". Apesar da amizade, existem conflitos entre o emigrante e o amigo "que ficou", principalmente com a persistência do narrador em fazer comentários sobre a identidade de Luís Henriques, em ressaltar o seu suposto jeito estrangeirado, categorizandoo como filho pródigo que retorna a terra paterna: "estava primeiro à espera de ver 
passar-te a mania de superioridade com que vocês, quer sejam simples imigrantes braçais quer sábios intelectuais, arrogantemente chegam a Cabo Verde" (AlmEIDA, 2010, p. 208).

É curioso notar que a maior parte das provocações parte do narrador, que referindo o presumido ar de superioridade do emigrante em relação à terra natal, se antecipa em fazer críticas aos problemas de infraestrutura em Cabo Verde, antes mesmo que Luís Henrique diga algo a este respeito. "O direito de dizer mal de Cabo Verde e dos cabo-verdianos pertence-nos a nós como prerrogativa exclusiva [...] nunca permitimos que estranhos a nós assumam o atrevimento de nos criticar" (ALMEIDA, 2010, p. 240).

Essa relação parece sugerir uma constante desconfiança e aversão por parte dos cabo-verdianos que vivem no arquipélago de serem inferiorizados pelos emigrantes, nomeadamente pelos que vivem na Europa, pelo desdém dos aspectos precários da realidade nacional. O narrador reforça: "não somos nós que vemos, são vocês que nos mostram que são, vocês é que chegam apresentando-se como estrangeirados [...] fazem troça da nossa pobreza como se nunca a tivessem conhecido e vivido e nada tivessem a ver convosco" (AlmeidA, 2010, p. 240-241). Luís Henriques protesta contra esses comentários, pois também nasceu e foi criado nas ilhas, ironizando esse "monopólio da cabo-verdianidade" (AlmeIDA, 2010, p. 22) que estaria então na mão dos residentes insulares, e uma identidade negada aos que partiram. De volta a Cabo Verde, os estrangeirados teriam que ser "domesticados" e reconvertidos para readquirirem a sua cabo-verdianidade.

Além de discutir essa distinção identitária entre os que permaneceram e os que emigraram, identificam-se outros lugares-comuns sobre o "ser cabo-verdiano" nos diálogos dos dois amigos, onde novamente impera o tom trocista dos personagens para jogar com essas particularidades que são atrelados aos cabo-verdianos. A aparência física, por exemplo, onde a miscigenação é vista como característica essencial da população: "este nosso povo que se dá até o luxo de afirmar a existência de uma raça cabo-verdiana e se permite o atrevimento de apreciar a beleza das mulheres estrangeiras pela sua maior ou menor parecença com as nossas mulheres" (ALMEIDA, 2010, p. 22), comentário que, além do mais, revela que a caboverdianidade, como tantas outras identidades nacionais, é construída a partir do olhar masculino que coloca as mulheres na posição de objetos. Outro elemento é a índole do povo e o seu pouco comprometimento com o trabalho, preconceito contestado e também confirmado pelo narrador. Ele afirma com autoironia que "nem todo cabo-verdiano é desleixado, que há pelo menos dois que prestam" (AlMEIDA, 2010, p. 237) e "como todo bom cabo-verdiano e como quase tudo o que se faz em Cabo Verde, largamos o trabalho à meio, depois de todas as despesas que já foram feitas" (AlmEIDA, 2010, p. 245).

A língua também é colocada como uma questão que une os que a utilizam e afasta indivíduos como Luís Henriques de ser um "cabo-verdiano de gema", que, quando se envolve romanticamente com Dulce, continua a utilizar o português, 
atitude rapidamente zombada pelo narrador, pois a "língua da conquista, do afecto, do namoro, é só crioulo e mais nenhum” (AlmEIDA, 2010, p. 184).

\section{A "estória da história" como pretexto}

Assim, reforçando o que Hall (1990) afirma sobre uma identidade construída no ato de recontar o passado, é importante entender a trajetória pessoal dos dois personagens, que estão envolvidos nesse papel de historiadores por um "conjunto de circunstâncias perfeitamente aleatórias" (AlmEIDA, 2010, p. 84) para perceber que recontar a estória de Bezerra de Oliveira não possui somente valor historiográfico, mas é também um pretexto para explorarem suas intenções pessoais. $\mathrm{O}$ narrador apega-se à figura do coronel como exemplo de grandeza do passado do arquipélago, momento de rompimento com a necessidade de "orientadores" externos para os cabo-verdianos. O coronel serve-lhe de pretexto para afirmar a sua própria grandeza e cabo-verdianidade, a honra de quem nunca deixou a sua terra, para defender e valorizar a cultura e o progresso nacional de Cabo Verde, sem deixar de reconhecer e criticar os impasses do presente.

Em Luís Henriques o desejo de reafirmação identitária é ainda mais visível, porque acaba funcionado como pretexto para a sua reconexão com as raízes caboverdianas. Conforme o livro progride, Luís Henriques reconquista até mesmo o direito de dizer mal da terra, e ganha o "aval" do narrador, que não o vê mais como estrangeirado. Apesar de entendermos que ele na verdade nunca negou a sua cabo-verdianidade (nunca quis regularizar os seus documentos para conseguir a cidadania portuguesa, já que na época isso implicaria renunciar à nacionalidade cabo-verdiana). O livro e a história de Bezerra são justificativas para, depois dos seus "quarenta anos de lisboeta", realizar a viagem às ilhas e uma verdadeira imersão na história e geografia de Cabo Verde, que permite reencontrar elementos da sua juventude e infância, como as praias e ruas que costumava frequentar, o seu envolvimento com Eva, a qual financia a sua passagem aérea; e permite até criar novas relações, como a inusitada amizade com Zé Manel, o esposo de Eva. Novo também é o seu envolvimento amoroso com Dulce, o que estimula a possibilidade de regresso definitivo. Destacável é o momento em que, confrontado por dizer uma palavra "indecente", Luís Henriques afirma: "sou filho dessas ilhas, rapaz [...], menino das areias da praia da Gamboa, conheço a coleção completa dos nomes ditos obscenos" (AlmEIDA, 2010, p. 260).

Os planos debochados do narrador de inseri-lo na vida política retomam a já referida relação entre Cabo Verde e a União Europeia. O narrador projeta o amigo, de maneira cada vez mais provocadora e cínica, como deputado no Parlamento Europeu em Estrasburgo: "ora, se continuarmos a namorar a Europa como vimos fazendo, a integração será uma questão de tempo e aí vamos precisar de deputados qualificados, porque para Estrasburgo não vamos mandar qualquer asneirento" (Almeida, 2010, p. 359). 


\section{Conclusões}

Pelo que mostramos, entende-se a proposta de Germano Almeida de afirmar e desafiar a identidade cabo-verdiana relativamente segura do valor do seu passado de nação cultural que precedeu o Estado em séculos, mas insegura do seu futuro e da sua relação com a Europa e a África. Por mais homogênea que possa aparecer, a cabo-verdianidade encontra-se, como todas as identidades, em permanente construção. O romance promove o discernimento crítico sobre a história do arquipélago, abrindo espaço para que seja novamente repensada, mas deixando também e inevitavelmente algumas portas fechadas que outros abrirão. Revirando os arquivos e textos historiográficos para trazer à luz um episódio histórico que poderia ficar esquecido, abandonado aos interesses coloniais, mas que é revisitado e reelaborado. O romance atribui heroicidade a um indivíduo exemplar de um período crucial da história cabo-verdiana que, mesmo que fracassado em mudar o curso dos acontecimentos, ainda assim conseguiu estabelecer resistência à metrópole e marcar uma época que "acabou por representar um corte absoluto entre dois Cabo Verde, aquele da autogestão e o outro colonial" (Almeida, 2010, p. 329).

O que pretendemos ressaltar no romance é a sua potencialidade de integrar a recuperação da história colonial no debate público de uma sociedade pós-colonial. Ao recontar essa história ficcionalizada, mas com o "imperativo realista" de uma "interpretação séria do passado" (DALley, 2014, p. 9), o autor preenche alguns espaços brancos, assume o controle sobre como narrar a própria história numa perspectiva cabo-verdiana e se posicionar nesta histórica/estória para construir e/ou reafirmar a cabo-verdianidade numa perspectiva que chamamos, com Madeira (2016, p. 54), singularista. Os elementos metaficcionais impulsionados na disputa amigável e irônica entre o narrador e Luís Henriques (que não reduzem, mas permitem posicionar a obra nas tendências pós-modernas), orientam a percepção dos limites da narrativa histórica e das relações entre o passado e o presente. Possibilitam também rir e refletir criticamente sobre como o povo compreende, afirma e questiona a sua própria identidade, que não se torna fixa no tempo, estando constantemente em reformulação. Aliando esses aspectos, A morte do ouvidor dialoga com as postulações sobre o romance histórico pós-colonial, onde "narratives of the past are at once interventions in the present, and dreams of possibilities to come" (DALley, 2014, p. 203).

\section{Referências}

Almeida, Germano. A morte do ouvidor. Lisboa: Caminho, 2010.

AlmeidA, Germano. Estórias Contadas: crónicas. Lisboa: Caminho, 1998.

Bergamo, Edvaldo A. Mulheres atlânticas em movimento: o romance histórico pós-colonial de Ana Miranda e de José Eduardo Agualusa. Iberoamericana. América Latina - España - Portugal, Vol. XVII, n. 66, p. 55-72, 2017. 
Cabral, Iva. António de Barros Bezerra de Oliveira, o Régulo da Ilha de Santiago. Portal do Conhecimento de Cabo Verde, 2012. Disponível em: http: //www.portaldoconhecimento.gov.cv/handle/10961/362. Acesso em: 25/o6/2020.

CABral, Iva. Elites atlânticas: Ribeira Grande do Cabo Verde (séculos XVIXVIII). Portal do Conhecimento de Cabo Verde, 2012. Disponível em: http: //www.portaldoconhecimento.gov.cv/handle/10961/362. Acesso em: 25/o6/2020.

Castelo, Cláudia. "O modo português de estar no mundo": O luso-tropicalismo e a ideologia colonial portuguesa (1933-1961). Porto: Edições Afrontamento, 22011 [1999].

Dalley, Hamish: The Postcolonial Historical Novel Realism, Allegory, and the Representation of Contested Pasts. New York: Palgrave Macmillan, 2014.

HALL, Stuart. Cultural identity and diaspora. In: Rutherford, Jonathan (ed.). Identity: community, culture, difference. London: Lawrence \& Wishart, p. 222-37, 1990.

Hamilton, Russel G.. Literatura africana, literatura necessária (Vol. II). Lisboa/Porto: Edições 70, 1984 .

Hutcheon, Linda. Poética do pós-modernismo. Trad. de Ricardo Cruz. Rio de Janeiro: Imago, 1991.

GóIs, Pedro. Emigração Cabo-Verdiana para (e na) Europa e a sua Inserção em Mercados de Trabalho Locais. Lisboa, Milão e Roterdão, Lisboa: Acıme, 2006.

LARANJEIra, Pires. A identidade "criola" e negro-africana e uma nova representação da mulher, com exemplos de Cabo Verde e São Tomé e Príncipe. In: Ribeiro, Margarida Calafate; Jorge, Sílvio Renato (orgs.). Literaturas Insulares. Leituras e escritas. Cabo Verde e S. Tomé e Príncipe. Porto: Afrontamento, 2011, p. 17-31.

LARAnjeira, Pires. Literatura africana de expressão portuguesa. Com I. Mata e E. Rodrigues dos Santos. Lisboa: Universidade Aberta, 1995.

Lopes Filho, João. Mestiçagem, emigração e mudança em Cabo Verde. África: Revista do Centro de Estudos Africanos. São Paulo: Usp, p. 129-140, 2010.

Madeira, João Paulo. A construção do Estado-Nação em Cabo Verde. In: Reis, Bruno Carriço (org.). Radiografia Crioula - Um diagnóstico político e social de Cabo Verde. Lisboa: Universidade Autónoma de Lisboa; Faro: Sílabas \& Desafios, 2016, p. $49-82$.

Pires, Maria do Carmo Martins. Escrever uma história libertadora sem rejeitar o borbulhar da modernidade: a busca impossível de Germano Almeida. Revista Cerrados, v. 25, n. 41, 2 ago. 2016.

Rattner, Jair. "Os portugueses acham que são donos da língua", Germano Almeida, escritor cabo-verdiano. Pessoa, revista de literatura lusófona, 6 de agosto de 2010. Disponível em: http://www.revistapessoa.com/2010/o8/os-portugueses- 
acham-que-sao-donos-da-lingua-germano-almeida-escritor-cabo-verdiano/. Acesso em: 22/06/2020.

Recebido em 19 de fevereiro de 2021.

Aprovado em 15 de junho de 2021.

\section{Resumo}

"O monopólio da cabo-verdianidade": A morte do ouvidor (2010), de Germano Almeida, e o desafio de recontar o passado

\section{Paulo Victor Alves Lima da Silva e Doris Wieser}

Analisando o romance A morte do ouvidor (2010), de Germano Almeida, este artigo propõe compreender o exercício de recontar o passado como resposta às demandas pós-coloniais de domínio e consciência sobre a história e como uma maneira de questionar e reformular as noções de identidade cultural em Cabo Verde. Ao observar os recursos historiográficos e metaficcionais mobilizados no romance para montar a trajetória do coronel António de Barros Bezerra de Oliveira, buscase perceber como os dois eixos em que se articula o romance exploram o passado e o presente de forma crítica, irônica e fragmentada, e abrem caminho para afirmar o "ser cabo-verdiano" e a possibilidades de novos posicionamentos.

Palavras-chave: romance histórico, Cabo Verde, identidade, metaficção. 